\title{
'When I was a child I thought as a child ...': The Importance of Memory in Constructions of Childhood and Social Order in a Selection of Post-disaster Fictions
}

\author{
Elizabeth Braithwaite
}

This paper will analyse the construction of childhood in three post-disaster texts for young readers: Ruth Hooker's Kennaquhair, Robert C. O'Brien's Z for Zachariah, and Hugh Scott's Why Weeps the Brogan?, exploring how the relationship between particular notions of childhood and memory are used to show protagonists' assumption of power and hence choice in how they respond to the social orders in which they find themselves. 'Power' has been defined in many ways, but I will use the definition which Roberta Trites draws from the work of Judith Butler: 'Power is the force that allows for subjectivity and consequently, agency' (Trites 2000, p.3). Whereas O'Brien's and Scott's novels place their protagonists in dystopian settings, Hooker's Kennaquhair presents a small-scale utopia and implies a younger readership than do the other two texts, and I will argue that the utopia in this text can only work in narrative terms because the novel is aimed at children rather than young adults.

In "“A useful knowledge of the present is rooted in the past": Memory and Historical Reconciliation in Ursula K. Le Guin's The Telling', Raffaella Baccolini explores the relationship between memory, history and utopia/dystopia, focusing especially on Le Guin's text. I intend to take three of the points Baccolini makes to use them to investigate the connection between memory, childhood and social order in Kennaquhair, $Z$ for Zachariah and Why Weeps the Brogan?:

1. All utopias and dystopias are dependent on their historical context for understanding ....

2. Memory is ... necessary to an understanding of oneself and of the past, but also of the present and of the future, and thus acquires a social dimension.

3. Only those who choose to remember are capable of taking responsibility for their actions and being accountable.

(Baccolini 2003, pp.114, 118, 119)

All three texts to be discussed in this paper belong to the genre of post-disaster fiction, that is, fiction set in the future 'after the world we know has been destroyed by cataclysmic disaster, usually caused by human actions'
(Stephens 1992,p.126). With a few exceptions, the general trend in post-disaster fiction (for children and young adults at least) has been that the type of disaster which creates the narrative situation in the text is a disaster of significant concern to the society in which the text was written. In this way, post-disaster fiction accords with part of Baccolini's explication of dystopia: 'Dystopia shows how our present may negatively evolve' (Baccolini 2003, p.115). As John Stephens notes, 'the purpose of the [post-disaster] genre is to issue a warning about destructive tendencies in human behaviour' (Stephens 1992, p.126) and while these 'destructive tendencies' can take a variety of forms, one of the functions of post-disaster fiction is to show what might happen if the disaster threatening the society in which the text was written becomes reality. As Jenny Mutton says of Brother in the Land, for example, 'The author's message is that what can happen to [the main protagonist] can happen to anyone. Take heed lest the situation in the novel become reality' (Mutton 1987, p.3). Accordingly, these three texts, as well as most other post-disaster texts for children and young adults that focus on the effects of an implied or stated nuclear disaster, were published during the Cold War years, whereas the general trend in more recent years has been to consider other types of disaster, such as ecological crises.

Rather than discuss the texts chronologically, I will begin by looking at Kennaquhair, which offers a utopia, and then consider how the dystopias of the other two texts compare with it. Kennaquhair is set after a major disaster; probably nuclear in origin since much of nature is dead, there are very few people around, and protective clothing and gas masks are required. Six children meet, without talking, and find their way to a secluded valley which has somehow escaped the effects of the disaster. The old man, 'Olmun', who lives in the valley invites the children to stay, gives them names, teaches them how to look after the farm, and encourages them to value each other's individual gifts and work as a team. When he leaves to go in search of his children and grandchildren (and also possibly in search of the valley children's own families) he leaves them with the injunction 'no fighting'. Without Olmun as the central authority, the children find it difficult to listen to each other, and a string of small carelessnesses leads 
to arguing and accusations. One child, Meeja, wants to leave the valley and another child, Alew, tries to stop her by causing the exit point from the valley to be blocked. Tensions follow but are resolved through the other five children working together to save the life of Alew, who has realised the implications of what she has done and tried to make amends by attempting to find another way to leave the valley. She almost drowns in her quest. The children learn through their experiences that they must value each other's interests, look after one another, obey the injunction of 'no fighting', and never forget how close they came to losing their community because of their quarrelling. The novel ends with an idyllic pastoral scene of the valley, and the children happy in their community with the added knowledge that Olmun (alone) knows where their valley is, and (implicitly) will someday return.

The social order within the valley in Kennaquhair is a 'eutopia within a dystopian situation': a potentially idyllic community in the midst of post-disaster destruction. The utopia relates closely to Lyman Tower Sargent's definition of 'Eutopia or positive utopia':

\begin{abstract}
A non-existent society described in considerable detail and normally located in time and space that the author intended a contemporaneous reader to view as considerably better than the society in which that reader lived.
\end{abstract}

(Sargent 1994, p.9)

The devastation wrought by the disaster is clearly not meant to be better than the reader's society, but the social order created in the valley calls upon a pastoral discourse in which nature represented as gentle and fertile, warm human relationships, and spiritual beliefs are combined to create an idyllic space. This is made clear through the poem created by the boy Talig, which appears twice in the novel, firstly when the valley community is functioning at its best, not long before Olmun decides to go in search of his family and possibly the children's:

\footnotetext{
'There is a valley

Where many streams flow

And many things grow

And people are friends.'

(Hooker 1976, p.74)
}

The poem appears again at the end of the novel, with an additional last line 'No one knows where' (Hooker 1976, p.159), which adds to the sense of the community as 'the good place but no place', thus invoking 'Thomas More's original pun - eutopos/outopos combined as utopia, hence the good place which is no place' (Levitas 2003, p.3). The name Kennaquhair ${ }^{1}$ itself echoes this: the inside of the dustjacket defines Kennaquhair as 'don't know where', and the etymology of this can be traced to 'ken' meaning 'to know', with the negative formed by adding 'na', (Dictionary of the Scots Language, online). The basic tenets of this small community within the valley are to value each other's skills and one's own, to be able to work together, and not to fight, ${ }^{2}$ tenets which Olmun highlights before he leaves the valley:

\section{"You will do very well. You each have special skills, and what's most important, you work well together on big jobs. You help one another. ”...}

"Rules?" Olmun said. "Yes, I've thought of rules. I've thought of many, but I've decided there is only one that I want to tell you. That rule is: no fighting."

(Hooker 1976, p.87)

As this suggests, Olmun is set up as an authority figure whom neither the reader nor the young protagonists are positioned to challenge, and the utopia in Kennaquhair can work only because the young protagonists, and by implication young readers, are prepared to accept the authority of Olmun without question. It is this construction of "child as willing to acquiesce to benevolent authoritative adult and rightly so' that particularly marks out Kennaquhair as a text for children (albeit older ones, given the subject matter) rather than young adults. Roberta Trites argues that:

The chief characteristic that distinguishes
adolescent literature from children's literature is
the issue of how social power is deployed during
the course of the narrative. In books that younger
children read ... much of the action focuses on
one child who learns to feel more secure in the
confines of her or his immediate environment,
usually represented by family and home. (Trites 2000, pp.2-3) 
In post-disaster fiction the original home has almost invariably been destroyed or irrevocably altered, but what happens in Kennaquhair is that the group of children (who have the same narrative function in this context as a single child in many other texts) find a new home and surrogate family where they are valued individually and where they feel they belong and can make a contribution to the ongoing welfare of the social order. Unlike Zfor Zachariah, which concludes with Ann leaving the valley in the hope of finding a community where she can be welcomed and useful, the children in Kennaquhair spend much of the narrative in their new home. In this way, Kennaquhair fits into a pattern suggested by Nodelman and Reimer: 'Many children's books ... describe how children journey away from homes whose security or happiness have been disrupted and finally find a new home representing the old security elsewhere' (2003, pp.190-191).

The nuclear disaster not only disrupts the children's original homes but also in all probability eliminates them; Alew says, '[Olmun] won't find anything for me. There is nothing' (Hooker 1976, p.120). The children's experiences as a result of the disaster, prior to when they came to the valley, also at least temporarily erase much of their sense of self and hence any potential to challenge the social order. Even when 'more and more they began to recall bits and pieces of things' (Hooker 1976, p.79), the nature of most of those 'bits and pieces' is not revealed to the reader, and hence the utopia remains free from the potential contamination of the children's memories. When the memories are recalled, they tend to draw attention to the value of life in the valley, as shown in the contrast between Meeja's nightmare in which she remembers feeling crushed, and her realisation on waking that 'There's lots of room in the valley' (Hooker 1976, p.148).

The community in the valley is run entirely along the wishes of Olmun, who is presented as knowing the children's needs better than they do. This is established very early on, in the scene in which the children all gather in Olmun's room. In contrast to the children's silence, Olmun's actions are narrated with words constructing him as a figure of power and authority: 'told them', 'must', 'decided', 'urged them':
No one spoke. Olmun talked to them. He told them what they must do to feed themselves. He watched carefully to see if they understood what he said. Sometimes they nodded; and sometimes they did not. When they didn't Olmun repeated the same thing until they did nod.

When he decided they knew enough, he urged them to go and do what he had told them.

It took much urging before they would move toward the door. It took even more urging before they would leave the room.

(Hooker 1976, p.18)

Everything is presented from the point of view of Olmun, and there is no sense of the children having any agency - they might just as well be trained dogs, or robots receiving instructions.

The overall image of childhood in Kennaquhair, then, is that of moral and experiential innocence, and as such a space on which adults can write. This is exemplified in the scene when Olmun gives the children names because they cannot (or will not) remember their own. Although the youngest child, Pummy, is reluctant to accept the name bestowed upon her by Olmun, ${ }^{3}$ this very reluctance is used to reaffirm the notion of the child as a being which can be interpellated by adults, constructed as being a particular sort of object. Instead of accepting the rather comic and childlike name 'Pummy', the little girl answers Olmun's question of 'Then what shall we call you?' by saying 'Nobody' (Hooker 1976, p.23). The relationship between name and a sense of self is reaffirmed — as is Olmun's authority — by Olmun's response to the other children after Pummy has refused her name: 'He shook his head sadly. "We must take special care of her," he told the others. "We will call her Pummy, and she will learn to answer to her name and know that she is somebody"' (1976, p.24). Implicitly, the 'somebody' Pummy will come to know herself to be will be congruent with Olmun's beliefs.

The idea of memory as 'necessary to an understanding of oneself and of the past, but also of the present and of the future, and thus acquir[ing] a social dimension' (Baccolini 2003, p.118) manifests itself in the children's decisions to continue to be part of the valley community even though 
their memories have started to return. This is especially obvious in the scene in which Shabin finds the protective suits that the children were wearing when they came to the valley. When he finds his suit, which had his previous name in it, and one of the other children asks 'What is your name?', he replies 'Shabin is my name now'. Similarly, when Rydeck asks 'Do you think Olmun knows our real names?', Talig answers by saying 'You mean our other names' (Hooker 1976, p.119). Their deliberate choice of maintaining the names bestowed on them by Olmun spells out both the children's developing power, in that they can now consciously choose the names given to them, and also their willingness to conform to the rules set up by Olmun for how life in the valley is to be run. The only note of dissent is from Meeja, who says 'I will be Meeja while I'm in the valley' (Hooker 1976, p.119), but even her willingness to accept the name given her for while she is in the valley shows her readiness to acquiesce to the valley's rules.

The importance of choosing to remember and hence to be accountable is made clear in the children's decision after their fight has been resolved that they must always remember what has happened in order to stop it ever happening again. It is Alew, the only one of the children who has fought against recalling her negative memories of life before the valley, who says 'We've got to remember. We can't forget how awful. How terrible. If we remember, we won't ever fight again'(Hooker 1976, p.158). After thought, the other children agree that they must never forget the importance of 'no fighting' (Hooker 1976, p.158), and the importance of this decision in terms of the text's ideology is reflected in the idyllic pastoral scene which follows their discussion: 'They rested on the beach in the quiet cove, happy that they were all together again. One of them sighed, then another. They were still, as still as the quiet water and the silent sun shining upon them' (Hooker 1976, p.158). Once again, a connection is implied between the children and quiet and peaceful nature, thus reinscribing an essentially positive view of the child.

The scenario in $Z$ for Zachariah is in some ways like Kennaquhair in reverse. Into a secluded valley, which has been protected from the nuclear fall-out by virtue of its geography and where a teenage girl lives alone, a solitary man arrives with a very different set of values and experiences. The girl, Ann, nurses the man (Mr Loomis) through a mild case of radiation sickness, and is prepared to share the valley with him even after he physically attacks her, but she eventually realises that he wants to have complete control over her, and she realises that the only way to be free is to leave the valley. Her plan before the war had been to become an English teacher, and she begins to dream of a classroom of children who are longing to learn to read but have no one to teach them. She is inspired and sustained by this dream, and the novel concludes with her stealing Mr Loomis' safe suit and leaving the valley in order to search for these children and a community that will welcome her.

As with Kennaquhair, the social order is based on a young person's acquiescence to the authority of an older person, and Ann's recollection of her own childhood demonstrates the social mores which have positioned her to acquiesce towards authority and be so compassionate towards $\mathrm{Mr}$ Loomis. She says, for example, 'I am not sure I have ever hated anyone - as a child I was taught that hatred was wrong', but she is able to move beyond the fetters of what she has been taught and acknowledge to herself that she wants 'to hurt him, and cause him grief' (O'Brien 1976, p.174).

Part of Ann's path to gaining personal power is her capacity to acknowledge her past and then move on from it, and one of the ways this is suggested in the novel is through its attitude towards religion. In Kennaquhair there is a close alignment between innocent child, the Christian religion and spirituality, as seen in Shabin's song about the 'starry night, a night divine' (Hooker 1976, p.49), which is a clear reference to Clappeau and Adams' 'O Holy Night'. By contrast, in $Z$ for Zachariah religion is aligned with childhood, and is something from which Ann must move on. Religion, community, the safety of childhood and the warmth of traditional family life combine in the construction of childhood which contrasts starkly with Ann's experiences as a young adult trying to survive after the war and deal with Mr Loomis:

For some reason, playing the hymns had made me feel sad, as if I were homesick even though I was at home. They made me think of Sunday School. 
When we went to school, regular school, we went on the bus with other children, but when we went to Sunday School we drove to Ogdentown in the car with my mother and father, dressed in our good clothes and it was always festive.

(O’Brien 1975, p.57)

Early in the novel Ann regularly goes to the church to pray, but she gradually gives up her religious practices. Religion becomes associated for her with a normality that she must leave behind: when she is living in the cave, for example, after Mr Loomis shoots her, she writes:

Once or twice I stopped off at the church, but that, like keeping up my notebook, I tended to neglect. It seemed strained. I do not know exactly why. Churches, I suppose, must be associated with normalcy. I did pray a bit, but only at odd times during the day. The Bible was out of reach in the house.

(O’Brien 1975, p.150)

Rather than being a support in itself, therefore, there's a sense that religion has supported Ann because it is part of her memories of pre-disaster life. In contrast to the isolation she is experiencing as a teenager in the postdisaster world, childhood is presented as a time of security in being with others, especially her nuclear family; as well as going to Sunday School in the car with her family, she recalls playing with her brother and their cousin, playing chess with her father, (O'Brien 1975, pp.12, 180) and the security of a rural family life:

Ipassed the house. Visions moved behind my eyes, and I saw the house as I had seen it as a child: climbing the front steps on the way to supper, or sitting on the porch at night, watching the fireflies. My grandfather rocked me on the swing, and I remember someone singing. Later I had sat on the swing at night weaving long, romantic dreams about my life to come; then, the war.

(O’Brien 1975, p.183)

This sense of memory as necessary to an understanding of 'oneself and of the past, but also of the present and the future' (Baccolini 2003, p.118) thus underpins $Z$ for Zachariah, and is particularly obvious in the scene above, in which Ann prepares to leave the valley. The grief that Ann feels is powerful because of its sensuality: climbing, rocking, singing, swinging, weaving dreams. But the final step that Ann must take is to work through the pain of defining herself in terms of her childhood:

... With each step I seemed to move further away from my own life as it had been; yet everything I saw tied me closer to the valley. I passed remnants of an old treehouse. What had I hoped for as a child? I strained to remember, but it seemed to me that nothing in my childhood had prepared me for this.

(O’Brien 1975, p.184)

Nonetheless, Ann's youthful dreams (if not necessarily her childhood ones) have informed her future. Her ambition to teach English partly so she can take graduate courses in 'English literature and writing'(O'Brien 1975, pp.99-100) can be seen to be the basis of a dream with more unselfish motives:

Coming night after night, it began to dominate my thoughts, so that first I hoped and then later believed in what it seemed to tell: there is another place where I can live. And I am needed there: there is a schoolroom lined with books, and children sitting at the desks. There is no one to teach them so they cannot read.

(O’Brien 1975, p.172)

This dream will thus be both Ann's redemption and those of the children. As in Kennaquhair, children are seen as needing to be taught but also as agents of hope.

By contrast with Ann, Mr Loomis is not interested in his past. This difference is one of the many ways in which the two characters are set up in opposition to each other, for while Ann uses her memories as the basis for understanding herself and considering how she is going to behave, $\mathrm{Mr}$ Loomis refuses to face his past which continues to torment him. Ann thinks:

... I thought that the murder of Edward, the months alone in the laboratory, the long desperate walks, also alone, through the dead countryside - all that had been so horrible and deadening it had blotted out everything else in his mind. When he 
thought back, that was what popped up, so he did not think back, not talk about the past.

(O’Brien 1975, p.118)

However, Mr Loomis' refusal to face up to having murdered Edward is ultimately the means by which Ann wields her ultimate power over Mr Loomis and secures her freedom. When Mr Loomis goes to shoot Ann, she confronts him by saying, without deliberately having intended to do so, 'Yes, ... you can kill me ... the way you killed Edward' (O'Brien 1975, p.187). It is possible to infer that once $\mathrm{Mr}$ Loomis has faced up to the truth of having killed Edward he is then able to acknowledge his fear of being left alone, and from there to move from his self-centredness to the point where he indicates a direction in which Ann might travel in order to have the best chance of finding life (O’Brien 1975, pp.187-188). Memory at various levels, both for Ann and Mr Loomis, has thus facilitated a more positive future.

Even more than Kennaquhair and Zfor Zachariah, Scott's Why Weeps the Brogan? plays out the importance of memory as a key to self-knowledge, understanding of relationships with others, and a possible path to the future. The novel is set four years and eighty-odd days after a nuclear war, and focuses on the experiences of Saxon and Gilbert, two children who are trying to survive in the ruins of the old British Library and Museum. The children have constructed their own exacting and non-negotiable rules for survival, which are the means by which they maintain their sanity. The children do not know what has caused them to be in this situation, although very strong hints are given to the reader, such as the sign on the door of the area in which the children obtain their food, which reads 'For Use Only During Atomic War' (Scott 1991, p.15). There seems to be nothing else alive in the children's world except for the Brogan, a mysterious creature whom the children feel compelled to feed, but for whom Saxon in particular feels strong loathing. The world of the museum is crumbling, and Saxon both longs and fears to remember what might exist beyond it. She gradually comes to realise that the Brogan is human and female, but as the Brogan falls to her death the children realise that she is their mother. As the children weep, a strange figure in a white suit descends to them, looking for someone called 'Sergeant
Denby'. He is surprised to find two children instead and the novel ends with Saxon articulating the answers to the chief narrative questions: 'We have been here four years, eighty-five days,' said Saxon. 'I am Saxon. This is my brother, Gilbert. Saxon and Gilbert Brogan. Our mother is dead' (Scott 1991, p.103).

Whereas both Kennaquhair and Z for Zachariah present memory as useful but relatively passive, a thing that sits in a person's mind like a storage bank, memory in Why Weeps the Brogan? is alive and potentially dangerous, especially for Saxon:

'Memory was a strange creature, strange as the Brogan, a hiding creature that lived in her mind's shadows, stirring sometimes from a deep sleep, but never wakening' (Scott 1991,p.27). The mention of the Brogan positions the reader to expect that uncovering the identity of the Brogan will somehow be tied to Saxon's memory, and the whole basis of Why Weeps the Brogan? can be seen in terms of this point. Put crudely, the Brogan weeps because a nuclear war has deprived her of contact with her children. But memory works differently for her than it does for the children: whereas memory for Saxon enables her to realise who she is, for the Brogan, memory is regret and frustration, hence she offers cheese at the feet of a statue of children not unlike her own, as well as exhibiting anger and sadness (Scott 1991, pp.68, 69).

As in $Z$ for Zachariah, the children in Why Weeps the Brogan draw on their past in order to construct their present. However, whereas Ann has ready access to her past through the clarity of her memories (which the reader is never positioned to doubt are accurate), the past for Saxon and Gilbert is not so easily accessible and is largely drawn on unconsciously. What that past might be, however, can be discerned through the rules by which the children live. Phrases such as 'You may pour me a third coffee' (Scott 1991,p.9) suggest a humorous mix between a middle-class way of talking (presumably from the children's parents) and a child's (or possibly a pre-disaster adult's) gluttony. Further, the fact that Saxon knows how to cook and what foods traditionally by Western standards go together, such as bread and butter and bacon to make sandwiches (Scott 1991, p.83) suggests a western middle-class pre-disaster 
life. The importance of finding out that the Brogan is their mother also emphasises the importance of the nuclear family, which again feeds into this discourse. As with $Z$ for Zachariah there is also an implied familiarity with the discourse of Christianity, although the focus here is more on the nature of God, who exists as a male, anthropomorphic Being who knows all things and brings help to people, even to providing the children with a fire extinguisher in order to kill the spiders (Scott 1991, p.38).

One of the ways in which the dystopia in Why Weeps the Brogan? is created is in the gap between what the reader knows and what the children (especially Saxon) can piece together from their memories. For example, there is a three way tension between Saxon's practical use of the scissors, her recollection of scissors as 'longer than her hand; with shining blades and green loops' which leads her to wonder 'Was this memory?', and the narrative's statement that the scissors are 'small ... [with ] flowers curled on the blades, and the metal sat dull, just silver, eighteenth century, Scottish' (Scott 1991, p.14). The reader is positioned to see this bewildered child, Saxon, using a priceless pair of antique scissors for a very practical purpose, while she puzzles over memories of a type of scissors that would be prosaic to the reader. There is thus a sense of cultural capital based around history in Why Weeps the Brogan?, which also extends to books, of which Saxon and Gilbert clearly understand the principle, even if they cannot attach meaning. For example, they know how a dictionary works: they know that the meaning is assigned to the word next to it, even if for them 'the meaning has no meaning' (Scott 1991, p.56).

Saxon, especially, intuitively knows that 'Memory is ... necessary to an understanding of oneself and of the past, but also of the present and of the future' Baccolini 2003, p.118) but for her it is agony, precisely because of its very importance. As she starts to realise the true nature of the Brogan she cries in agony, recalling a scene of pre-disaster life:

'I am being stupid,' she wept. 'I do not wish to know! I will not - I will not remember!'

Gilbert held her. And she sobbed, destroying her thoughts with misery.
'It's the stone,' she whimpered. 'Falling on the steps behind the great doors. and the shoe, bright as blood - and trees, alive like the daisy is alive, and the ceiling of the world shining, oh! with glorious light!'

(Scott 1991, p.97)

Part of the tragedy of this scene is invoked by the naively childish description of the 'ceiling of the world', for Saxon and Gilbert, imprisoned in their dystopia for more than four years, cannot remember the sky. Choosing to remember, and dealing with the pain, is thus presented as a vital step in the characters' search for self-understanding and determination.

Vincent Geoghegan writes, 'My past memories will have a constitutive role in the forming of my present and future perceptions' (Geoghegan 1990, p.54), and the importance of memory as a tool for gaining access to a sense of self, the opportunity to make informed decisions, and as a way of having choice over future directions, is presented as vital in Kennaquhair, $Z$ for Zachariah and Why Weeps the Brogan?. Although characters may be drawing on memories from a childhood controlled by adults, or may currently be in a state where their status as children means that they are struggling to comprehend the world around them, all three texts suggest that childhood is innately innocent, and that it can be called upon through memory or invoked through experience to support a positive social order, to challenge a negative one, or to enable a transition toward self-actualisation.

This essay is an outcome of a project funded by the Australian Research Council.

\section{NOTES}

1. The word itself most probably originates in Sir Walter Scott's The Monastery, and a footnote in Scott's text explains that Melrose was 'the prototype of Kennaquhair' (Scott n.d., p.457).

2. It is very tempting to read these principles as suggestions of how - at a very rudimentary level, in keeping with the implied age level readership — to stop the disaster happening at all, especially if the disaster is presumed to be have been nuclear war rather than nuclear accident. 
3. The name 'Olmun' is a corruption of the name the man has asked the children to call him, 'Old Man' (Hooker 1976, p.17). Even though this corruption has come about through the children's mispronunciation, it is still clear that the adult in the novel has chosen the name by which he will be addressed, since he agrees that 'Olmun ... is good enough. That will be my name."

\section{REFERENCES}

Baccolini, Raffaella (2003), “"A useful knowledge of the present is rooted in the past": memory and historical reconciliation in Ursula K. Le Guin's The Telling', in R. Baccolini and T. Moylan (eds) Dark Horizons: Science Fiction and the Dystopian Imagination. Routledge, New York and London, pp.113-134.

Geoghegan, Vincent (1990) 'Remembering the Future', Utopian Studies 1, 2: 52-68.

Hooker, Ruth, Illustrated by Albert Michini (1976) Kennaquhair. Nashville, Abingdon. http:// www.dsl.ac.uk/ds1/ Dictionary of the Scots Language. Retrieved October 26, 2005.

Levitas, Ruth (2003) 'Introduction: the elusive idea of utopia', History of the Human Sciences 16, 1: 1-10.

Mutton, Jenny (1987) 'Beyond Armageddon' S.M.M.A.A.R.T. 1987, 1: 3-9.

Nodelman, Perry and Mavis Reimer (2003) The Pleasures of Children's Literature. Third Edition. Boston, Allyn and Bacon.

O’Brien, Robert C. [1975] (1976) Zfor Zachariah. London, Fontana Lions.

Sargent, Lyman Tower (1994) 'The three faces of utopia revisited' Utopian Studies 5, 1: 1-37.

Scott, Hugh [1989] (1991) Why Weeps the Brogan? London, Walker.

Scott, Sir Walter (n.d.) The Monastery. London, T. Nelson.

Stephens, John (1992) 'Post-disaster fiction: the problematics of a genre', Papers 3, 3: 126-130.
Trites, Roberta Seelinger (2000) Disturbing the Universe: Power and Repression in Adolescent Literature. Iowa City, University of Iowa Press.

\section{BIOGRAPHICAL NOTE}

Elizabeth Braithwaite is completing a $\mathrm{PhD}$ at the University of Melbourne on Young Adult post-disaster fiction. For the last three years she has been working as a ResearchAssistant for the funded ARC project 'Transformative

Utopianism: Contemporary Children's Literature Responding to Changing World Orders from Glasnost to 11 September, 2001'. 